\title{
A viral RNA competitively inhibits the antiviral endoribonuclease domain of RNase $L$
}

\author{
HANNAH L. TOWNSEND, ${ }^{1,5}$ BABAL K. JHA, ${ }^{2,5}$ JIAN-QIU HAN, ${ }^{1}$ N. KARL MALUF, ${ }^{3}$ \\ ROBERT H. SILVERMAN, ${ }^{2}$ and DAVID J. BARTON ${ }^{1,4}$ \\ ${ }^{1}$ Department of Microbiology, University of Colorado Denver, School of Medicine, Aurora, Colorado 80045, USA \\ ${ }^{2}$ Department of Cancer Biology, The Lerner Research Institute, The Cleveland Clinic Foundation, Cleveland, Ohio 44106, USA \\ ${ }^{3}$ Department of Pharmaceutical Sciences, University of Colorado Denver, School of Pharmacy, Aurora, Colorado 80045, USA \\ ${ }^{4}$ Program in Molecular Biology, University of Colorado Denver, School of Medicine, Aurora, Colorado 80045, USA
}

\begin{abstract}
Ribonuclease L (RNase L) is a latent endoribonuclease in an evolutionarily ancient interferon-regulated dsRNA-activated antiviral pathway. 2'-5' oligoadenylate (2-5A), the product of dsRNA-activated oligoadenylate synthetases (OASes), binds to ankyrin repeats near the amino terminus of RNase $\mathrm{L}$, initiating a series of conformational changes that result in the activation of the endoribonuclease. A phylogenetically conserved RNA structure within group $C$ enteroviruses inhibits the endoribonuclease activity of RNase L. In this study we report the mechanism by which group C enterovirus RNA inhibits RNase L. Viral RNA did not affect 2-5A binding to RNase $L$. Rather, the viral RNA inhibited the endoribonuclease domain. We used purified RNase $L$, purified 2-5A, and an RNA substrate with a 5' fluorophore and 3' quencher in FRET assays to measure inhibition of RNase L activity by the viral RNA. The group C enterovirus RNA was a competitive inhibitor of the endoribonuclease with a $K_{i}$ of 34 nM. Consistent with the kinetic profile of a competitive inhibitor, the viral RNA inhibited the constitutively active endoribonuclease domain of RNase $L$. We call this viral RNA the RNase L competitive inhibitor RNA (RNase L ciRNA).
\end{abstract}

Keywords: 2-5A; antiviral countermeasure; dsRNA; innate antiviral immunity; poliovirus

\section{INTRODUCTION}

Considering the RNA World hypothesis (Maizels and Weiner 1999), RNA viruses are contemporary microorganisms with evolutionarily ancient replication strategies. RNA viruses replicate via complementary RNAs that have the capacity to form dsRNA. Innate immunity, which is commonly triggered by viral dsRNAs in eukaryotic cells (Wang and Carmichael 2004), shares evolutionarily ancient origins with RNA viruses. Consequently, coevolutionary forces resulted in contemporary RNA viruses that use various strategies to minimize or sequester dsRNAs within cells (Ahlquist 2006). Furthermore, RNA viruses express various countermeasures to dsRNA-activated antiviral host responses (Goodbourn et al. 2000; Garcia-Sastre 2004; Gale and Foy 2005; Haller et al. 2006).

\footnotetext{
${ }^{5}$ These authors contributed equally to this work.

Reprint requests to: David J. Barton, Department of Microbiology, University of Colorado Denver, School of Medicine, Mail Stop 8333, 12800 East 19th Avenue, P.O. Box 6511, Aurora, CO 80045, USA; e-mail: david.barton@uchsc.edu; fax: (303) 724-2446.

Article published online ahead of print. Article and publication date are at http://www.rnajournal.org/cgi/doi/10.1261/rna.958908.
}

The $2^{\prime}-5$ ' oligoadenylate synthetase (OAS)/ribonuclease L (RNase L) pathway (for reviews, see Player and Torrence 1998; Silverman 2007) is particularly intriguing in light of the RNA World hypothesis. 2'-5' OASes are unusual RNA polymerases that require dsRNA as an allosteric activator (Desai and Sen 1997). dsRNA interacts with an RNA binding domain composed of a positively charged groove on the back of $2^{\prime}-5^{\prime}$ OAS (Hartmann et al. 2003). Upon binding dsRNA, 2'-5' OASes polymerize ATP into $2^{\prime}-5^{\prime}$ oligoadenylate $(2-5 A)$. In the absence of $2-5 A$, RNase $L$ is monomeric and inactive (Fig. 1A; Dong and Silverman 1995). Ankyrin repeats at the $\mathrm{NH}$ terminus of RNase $\mathrm{L}$ comprise a 2-5A binding domain (Tanaka et al. 2004; Nakanishi et al. 2005). Binding of 2-5A induces conformational changes in RNase $\mathrm{L}$ that lead to dimerization and activation of the endoribonuclease domain (Fig. 1A; Dong et al. 2001). While the atomic structure of the 2-5A binding domain of RNase L was elucidated (Tanaka et al. 2004), the atomic structures of the kinase-like and endoribonuclease domains are not yet known. The atomic structure of Ire1 (Lee et al. 2008), which shares common amino acid residues in the kinase and endonuclease domains of the larger Ire1/RNase L ribonuclease family, provides insight into the 
A
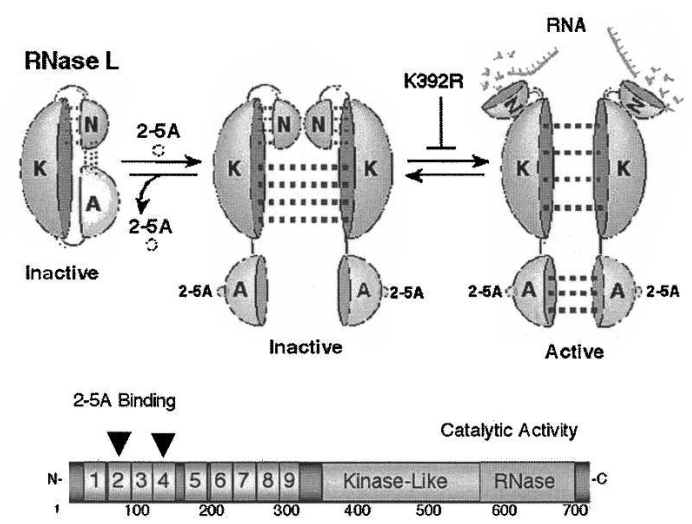

\section{B}

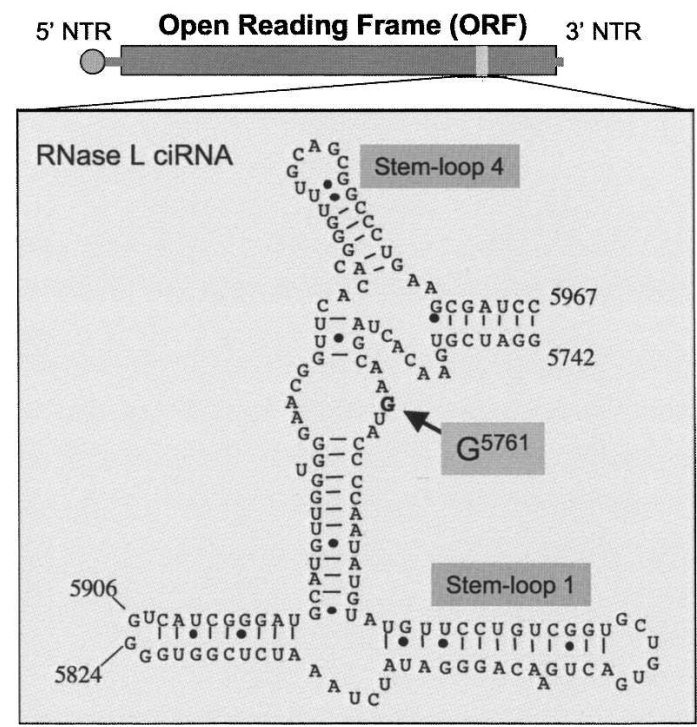

FIGURE 1. RNase L activation scheme and group C enterovirus RNA associated with inhibition of RNase L. (A) RNase L is monomeric in its inactive state. 2-5A binding to ankyrin repeats 2 and 4 (black arrows) (Tanaka et al. 2004) leads to conformational changes and RNase $\mathrm{L}$ dimerization culminating in the activation of the endoribonuclease domain. (Adapted from Dong et al. 2001 and reprinted with permission from RNA Society (C) 2001 [http://www.rnajournal.org/].) Specific portions of RNase L as identified in the cartoon: ankyrin repeat domain (A), kinase-like domain $(\mathrm{K})$, and endoribonuclease domain $(\mathrm{N})$. (B) RNase L competitive inhibitor RNA (RNase L ciRNA) from the $3 \mathrm{C}^{\mathrm{ORF}}$ of poliovirus RNA (Han et al. 2007).

structures of these domains in RNase L. RNase L with a $\mathrm{K} 392 \mathrm{R}$ mutation is unable to activate endonuclease after 2-5A binding (Dong and Silverman 1999). Presumably, conformational changes induced by $2-5 \mathrm{~A}$ binding lead to the activation of RNase L, and portions of the kinase domain of RNase L contribute to dimerization (Fig. 1A). Although wild-type RNase L is completely dependent upon $2-5 \mathrm{~A}$ for activation, unnatural truncated forms of RNase L composed of the endoribonuclease domain are constitutively active in the absence of 2-5A (Dong and Silverman 1997). A host protein called RNase L inhibitor (RLI) can contribute to the regulation of RNase L activation by pre- venting 2-5A binding (Bisbal et al. 1995; Benoit De Coignac et al. 1998; Bisbal et al. 2001). Activated RNase L cleaves heteropolymeric viral and cellular RNA predominantly at single-stranded UA and UU dinucleotides (FloydSmith et al. 1981; Wreschner et al. 1981).

A phylogenetically conserved RNA structure within the open reading frame (ORF) of group $\mathrm{C}$ enteroviruses is resistant to cleavage by RNase $\mathrm{L}$ and potently inhibits the antiviral endoribonuclease RNase L (Fig. 1B; Han et al. 2007). The RNA structure associated with the inhibition of RNase L involves two poliovirus (PV) RNA sequences, nucleotides 5742-5824 and nucleotides 5906-5967 in the $3 \mathrm{C}$ protease gene of the ORF (Fig. 1B; Han et al. 2007). The loop sequences in stem-loops 1 and 4 are complementary and appear to mediate a pseudoknot or kissing interaction (Xayaphoummine et al. 2005; Han et al. 2007).

In this study we sought to determine the mechanism by which this group C enterovirus RNA inhibited RNase L. Theoretically, PV competitive inhibitor RNA (ciRNA) could inhibit any step of RNase L activation (RNase L activation illustrated in Fig. 1A). PV ciRNA could inhibit 2-5A binding to RNase L, RNase L dimerization, or the endonuclease domain of RNase L (Fig. 1A). As reported herein, biochemical and kinetic analyses indicate that this viral RNA is a competitive inhibitor of the endoribonuclease domain of RNase L.

\section{RESULTS}

\section{FRET assay of RNase $L$ activity and inhibition by group $C$ enterovirus RNA}

We adapted a simple FRET-based RNase L activity assay to measure the ability of PV RNA to inhibit RNase L (Fig. 2; Geselowitz et al. 2000; Thakur et al. 2005). This assay uses an RNA oligonucleotide FRET probe with 6-carboxyfluorescein (6FAM) covalently attached to the $5^{\prime}$ end and Black Hole Quencher-1 (BHQ1) attached at the 3' end (SigmaProligo) (Fig. 2A). When the RNA oligonucleotide FRET probe is cleaved by nuclease, the BHQ1 can no longer effectively quench fluorescence.

Fluorescence did not increase over time when $100 \mathrm{nM}$ FRET probe was incubated in reactions without $2-5 \mathrm{~A}$ and RNase L (Fig. 2B, "Probe Alone"). Likewise, fluorescence did not increase when FRET probe was incubated in reactions with RNase $\mathrm{L}$ or $2-5 \mathrm{~A}$ alone (Fig. $2 \mathrm{~B}$, Probe + RNase $\mathrm{L}$ and Probe $+2-5 \mathrm{~A})$. Fluorescence did increase over time when FRET probe was incubated in reactions containing both $20 \mathrm{nM} 2-5 \mathrm{~A}$ and $20 \mathrm{nM}$ RNase L (Fig. 2B, Probe $+2-5 \mathrm{~A}+\mathrm{RNase} \mathrm{L}$, filled squares). Thus, both $2-5 \mathrm{~A}$ and RNase $\mathrm{L}$ were required to cleave the FRET probe. Reactions reached completion after 30 min of incubation. Increasing concentrations of PV 2123 RNA, a negative control RNA susceptible to cleavage by RNase L, did not inhibit cleavage of FRET probe (Fig. 2C). Although small 
B

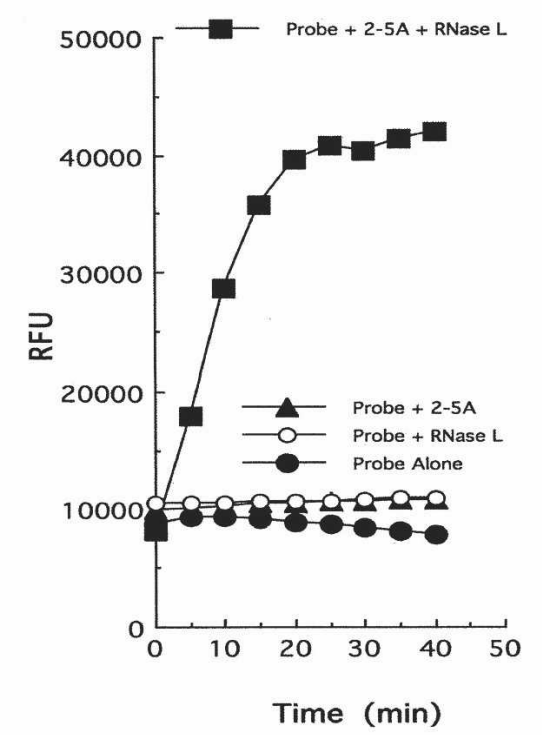

C

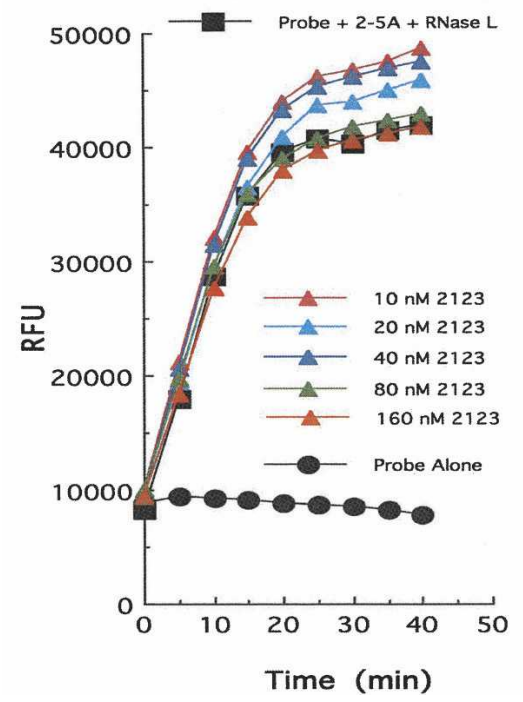

D

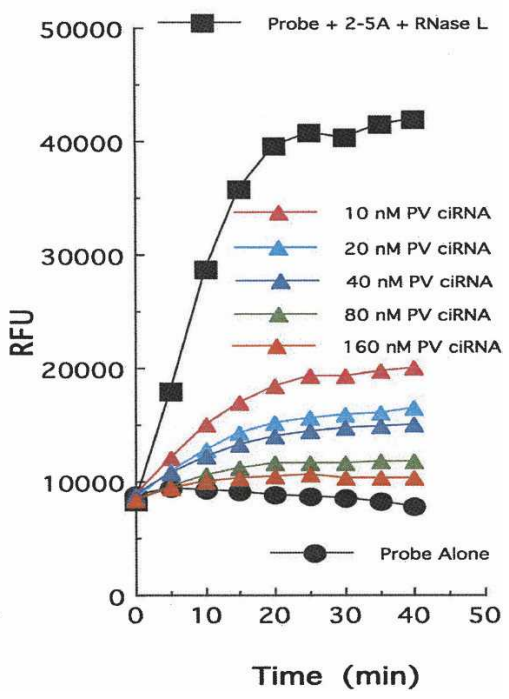

FIGURE 2. FRET assay of RNase L activity and inhibition of RNase L activity by viral RNA. (A) A 36-nt intergenic sequence of RSV labeled with a fluorophore (6FAM) at the $5^{\prime}$ end and a quencher (BHQ1) at the $3^{\prime}$ end was used as a substrate to detect RNase L activity. (B) Control reactions containing probe alone without RNase $\mathrm{L}$ or $2-5 \mathrm{~A}(\bullet)$, containing probe with $2-5 \mathrm{~A}$ $(\boldsymbol{\Delta})$, containing probe with RNase $\mathrm{L}(\mathrm{O})$ or Probe $+2-5 \mathrm{~A}+$ RNase $\mathrm{L}(\boldsymbol{\square})$. (C) FRET reactions

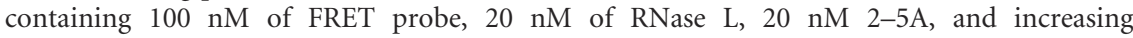
concentrations (10-160 nM) of 2123 RNA, a 300 base fragment of PV RNA not associated with the inhibition of RNase L (Han et al. 2007). (D) FRET reactions containing $100 \mathrm{nM}$ of FRET probe, $20 \mathrm{nM}$ of RNase L, $20 \mathrm{nM} 2-5 \mathrm{~A}$, and increasing concentrations (10-160 nM) of PV RNase L ciRNA. Relative fluorescence units (RFU) plotted versus time of incubation. Representative data from independent experiments.

amounts of the negative control PV 2123 RNA slightly stimulated cleavage of the FRET probe in this experiment, larger amounts had no effect (Fig. 2C). The small amount of stimulation associated with small amounts of 2123 RNA is inexplicable. In contrast, increasing amounts of the phylogenetically conserved PV ciRNA illustrated in Figure $1 \mathrm{~B}$ inhibited RNase $\mathrm{L}$ in the FRET assay (Fig. 2D). Notably, $20 \mathrm{nM}$ of ciRNA was able to inhibit $20 \mathrm{nM}$ of activated RNase L by $>50 \%$ (Fig. 2D). A four- to eightfold molar excess of ciRNA relative to RNase $\mathrm{L}$ resulted in $>90 \%$ inhibition of RNase L activity (Fig. 2D, 80-160 nM ciRNA). Thus, a modest molar excess of this ciRNA significantly inhibited RNase L activity.

\section{G5761A mutation in PV RNA abrogated inhibition of RNase $\mathbf{L}$}

The $G$ at position 5761 in the PV ORF is a wobble position of a lysine codon (AAG). This nucleotide, which is unpaired in the RNA structure predicted by Mfold (Fig. 1B) and kinefold, is absolutely conserved in more than 50 independent group C enteroviruses (data not shown). Mutation of this one residue completely abrogated the inhibition of RNase L (Fig. 3). As in Figure 2, probe alone served as a negative control (Fig. 3, probe alone). Relative fluorescence units (RFUs) increased for 10-20 min when the RNA probe was incubated with RNase $\mathrm{L}$ and $2-5 \mathrm{~A}$ (Fig. 3, Probe + RNase L and 2-5A). RFUs did not increase with additional time of incubation beyond $20 \mathrm{~min}$, indicating that the probe had been cleaved to completion (Fig. 3); 150 and $300 \mathrm{nM}$ PV ciRNA inhibited cleavage of the RNA probe (Fig. 3). In contrast, the same concentrations of PV ciRNA with the $\mathrm{G}^{5761}$ A mutation did not inhibit cleavage of the FRET probe (Fig. 3, 150 and 300 $n M G^{5761} A$ ciRNA). Rather, as seen with some concentrations of the negative control RNA used in Figure 2, $\mathrm{G}^{5761} \mathrm{~A}$ ciRNA modestly stimulated RNase L cleavage of the FRET probe (Fig. 3). Thus, a single point mutation at a highly conserved residue within the RNA structure abrogated inhibition of RNase L.

To explore the specificity of the inhibitory RNA, we tested whether endoribonuclease A (RNase A) or endoribonuclease T1 (RNase T1) activity was affected by the ciRNA. RNase A and T1 cleaved the FRET probe; however, the PV RNA did not inhibit either RNase 


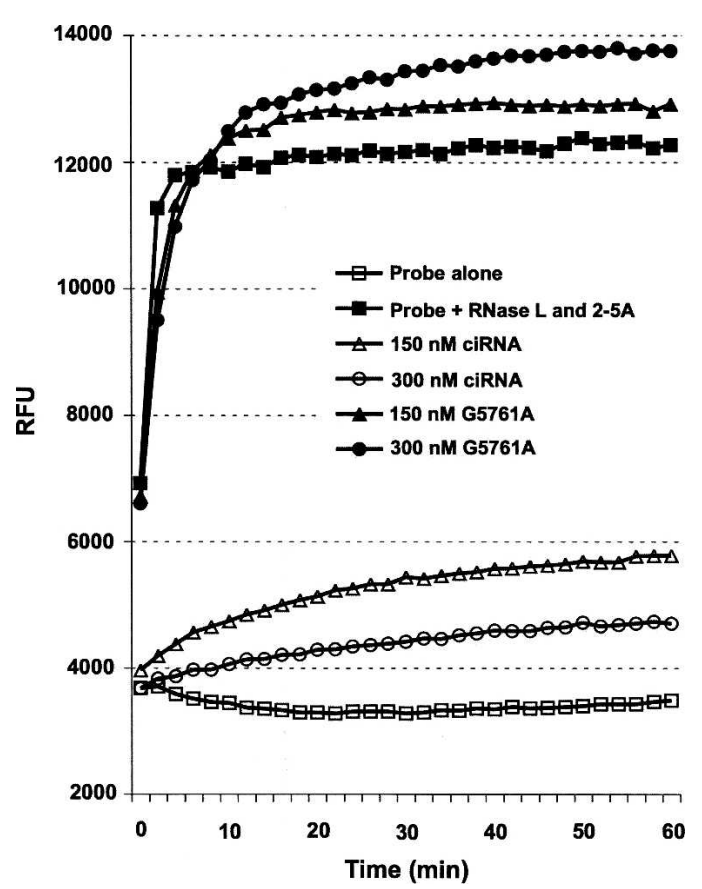

FIGURE 3. G5761A mutation within ciRNA abrogates inhibition of RNase L. FRET reaction containing $100 \mathrm{nM}$ of FRET probe, $20 \mathrm{nM}$ RNase L, and $20 \mathrm{nM} \mathrm{2-5A} \mathrm{( \square )} \mathrm{as} \mathrm{described} \mathrm{in} \mathrm{Materials} \mathrm{and} \mathrm{Methods.}$ FRET reaction containing probe without RNase $\mathrm{L}$ or $2-5 \mathrm{~A}$ ( $\square$ ). FRET reactions containing $100 \mathrm{nM}$ of FRET probe, $20 \mathrm{nM}$ RNase L, $20 \mathrm{nM}$ 2-5A, and either $150 \mathrm{nM}$ ciRNA $(\triangle), 300 \mathrm{nM}$ ciRNA ( $\bigcirc), 150 \mathrm{nM}$ $\mathrm{G}^{5761} \mathrm{~A}$ ciRNA $(\boldsymbol{\Delta})$ or $300 \mathrm{nM} \mathrm{G}{ }^{5761} \mathrm{~A}$ ciRNA $(\bullet)$. Relative fluorescence units (RFU) plotted versus time of incubation.

A or T1 (data not shown). These data indicated that the conserved portion of the PV $3 \mathrm{C}^{\mathrm{Pro}} \mathrm{ORF}$ was a potent and specific inhibitor of RNase L.

\section{2-5A binding to RNase $\mathrm{L}$}

Having established that PV encodes an RNA structure that can potently inhibit RNase L, we pursued experiments to determine the mechanism by which the viral RNA inhibits RNase L. As illustrated in Figure 1A, 2-5A-dependent activation of RNase L proceeds through several steps: 2 $5 \mathrm{~A}$ binding to RNase $\mathrm{L}$, dimerization of RNase $\mathrm{L}$, and further conformational changes after dimerization that lead to activation of the endoribonuclease domain (Fig. 1A). The PV RNA could conceivably inhibit any of these steps of activation or directly inhibit the endoribonuclease domain.

To address one of these possible mechanisms of inhibition, we measured 2-5A binding to RNase $\mathrm{L}$ in the presence and absence of PV RNA (Fig. 4). PV RNA 2122, a 303nucleotide (nt) portion of the PV 3C ORF that contains the ciRNA, was used along with three deletion mutants $(\Delta 1$, $\Delta 2$, and $\Delta 3$ ) of 2122 RNA (Fig. $4 \mathrm{~A}$ ). The $\Delta 1$ deletion removed stem-loop 1 found within the RNA structure associated with the inhibition of RNase L whereas the $\Delta 2$ and $\Delta 3$ deletions removed sequences from 2122 RNA that reside outside the portion of ORF required for inhibition of RNase L (as previously reported in Han et al. 2007). Biotinylated 2-5A bound to RNase $\mathrm{L}$ was detected by Streptavidin-HRP (Fig. 4B). While increasing amounts of unlabeled 2-5A (homologous competitor) effectively competed for binding of biotinylated 2-5A to RNase L, neither wild-type PV RNA (2122) nor mutant PV RNAs $(\Delta 1, \Delta 2$, or $\Delta 32122$ RNAs) diminished binding of 2-5A (Fig. 4B). Nonetheless, wild-type PV 2122 RNA effectively inhibited RNase L activity as measured in the FRET assay (Fig. 4C). Likewise, PV $2122 \Delta 2$ and $\Delta 3$ RNAs effectively inhibited RNase L whereas PV $2122 \Delta 1$ RNA failed to inhibit RNase L (Fig. 4C). These results indicated that PV RNA had no effect on 2-5A binding to RNase L. Consequently, we pursued steady state kinetic analyses to determine whether the PV RNA associated with the inhibition of RNase L was a competitive or noncompetitive inhibitor of RNase L.

\section{Kinetic analyses of RNase L}

Kinetics of RNase L activity were measured in reactions containing $20 \mathrm{nM}$ RNase L, $20 \mathrm{nM}$ of $2-5 \mathrm{~A}$, increasing concentrations of ciRNA (0-400 nM RNase L ciRNA from $\mathrm{PV})$, and increasing concentrations of RNA substrate (0.2$6 \mu \mathrm{M}$ FRET probe) (Fig. 5). As the amounts of RNA substrate were increased relative to the amounts of RNase L, the time required for reactions to reach completion increased (Fig. 5, note the $0 \mathrm{nM}$ ciRNA data points). Reactions containing $0.2 \mu \mathrm{M}$ substrate reached completion in $\sim 10$ min whereas reactions containing $>3 \mu \mathrm{M}$ substrate failed to reach completion until after $50 \mathrm{~min}$ of incubation (Fig. 5, $0 \mathrm{nM}$ ciRNA). Increasing amounts of ciRNA resulted in increased inhibition of each reaction (Fig. 5, 0$400 \mathrm{nM}$ ciRNA). Notably, increasing concentrations of substrate reduced the inhibition of RNase L by ciRNA (Fig. 5, compare magnitudes of inhibition in reactions containing $0.2 \mu \mathrm{M}$ substrate with magnitudes of inhibition in reactions containing $6 \mu \mathrm{M}$ substrate). As the substrate concentrations increased, the magnitude of inhibition by ciRNA decreased, consistent with the principle of a competitive inhibitor.

To further analyze these data, the initial velocity of RNase L activity was plotted versus the concentration of RNA substrate, at each inhibitor concentration examined (Fig. 6). The data were globally analyzed by nonlinear least squares according to a competitive inhibition model (see equation in Materials and Methods). The competitive inhibition model describes the data well and attempts to use more complex models that assume an allosteric mode of inhibition did not improve the quality of the fit. In fact, this result indicates these data contain no "information" to support a model that would assume the inhibitor binds to a site distinct from the substrate binding site, affecting allosterically the enzyme activity. If this were the case, the competitive inhibition model could not describe the data 


\section{A}

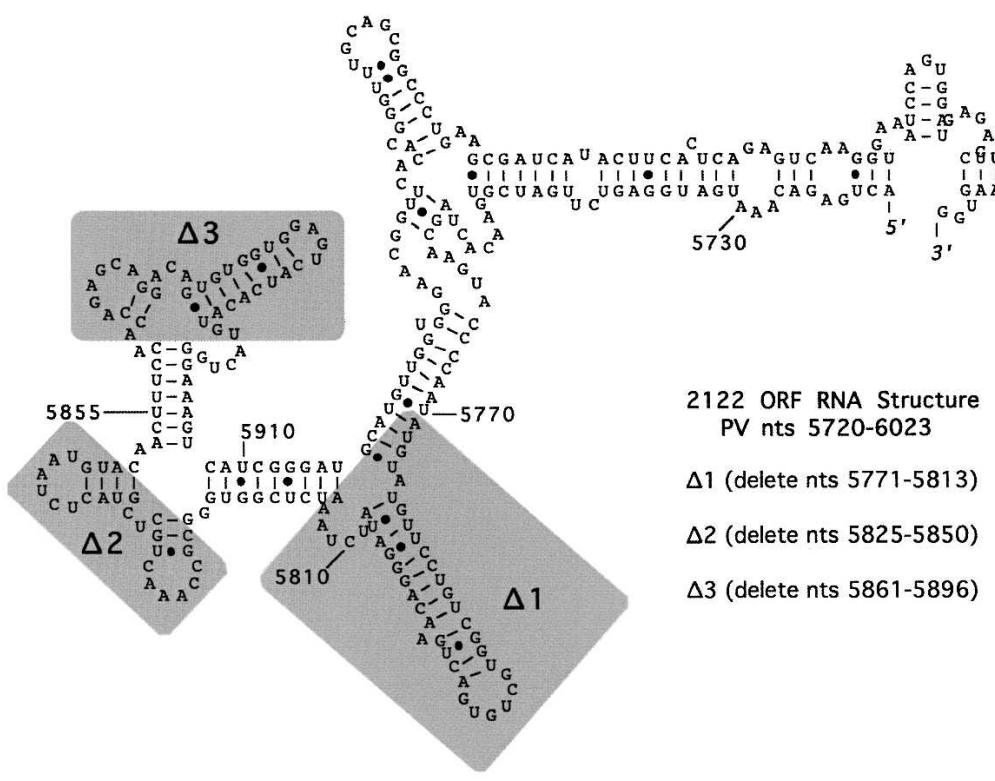

B

\section{C}
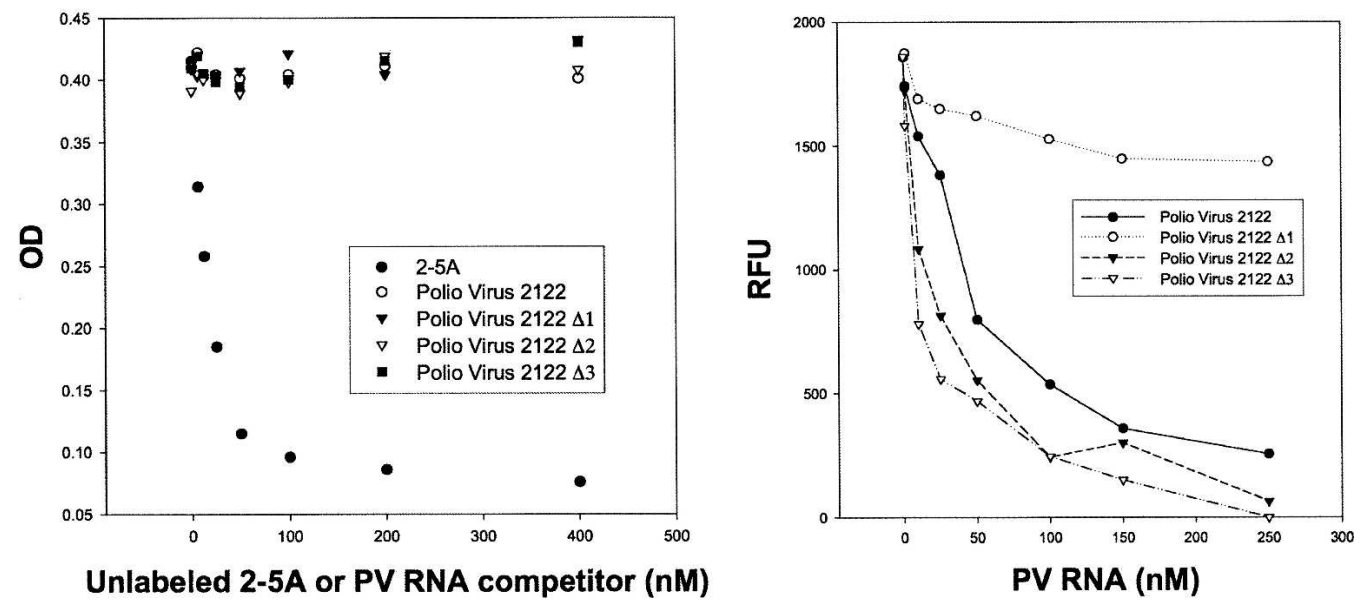

FIGURE 4. 2-5A binding to RNase L was unaffected by PV RNA. (A) RNA structure of PV 2122 RNA as predicted by M-fold (Mathews et al. 1999; Zuker 2003) and sequences affected by $\Delta 1, \Delta 2$, and $\Delta 3$ deletions (as in Han et al. 2007). (B) 2-5A binding assay. RNase $\mathrm{L}$ fixed to microtiter plates was incubated with increasing amounts of PV RNA 2122, $\Delta 1, \Delta 2, \Delta 3$ RNA derivatives or unlabeled 2-5A (0-400 nM). Biotin-labeled 2-5A was then added to each well. The amounts of biotin-labeled 2-5A bound to RNase L were detected with Streptavidin-HRP as described in Materials and Methods. (C) FRET assay. Increasing concentrations of PV 2122 RNA or its deletion mutant derivatives were incubated with fulllength wild-type RNase L (12.5 nM) for $10 \mathrm{~min}$; $100 \mathrm{nM}$ of FRET probe (Fig. 2A) was added to the above mixture and finally 2-5A was added. The cleavage of the FRET probe was monitored and plotted against increasing concentration of PV 2122 RNA and its deletion mutant derivatives.

(Segel 1975). The resulting best-fit parameters for $K_{\text {cat }}, K_{m}$, and $K_{i}$ were $5.9 \pm 0.3 \mathrm{~min}^{-1}, 860 \pm 200 \mathrm{nM}$, and $34 \pm 8$ $\mathrm{nM}$ (Table 1). Thus the apparent affinity of RNase L for the RNA probe substrate (in the steady state) was $860 \mathrm{nM}$, while the affinity of the ciRNA to RNase L was $34 \mathrm{nM}$. The uncertainties reported above were estimated using a Monte Carlo procedure (as described in Straume and Johnson 1992) and correspond to $68 \%$ confidence intervals. Thus, these data indicated that the PV RNA molecule was a competitive inhibitor of RNase L.

\section{PV RNA inhibits the endoribonuclease domain of RNase $L$}

Because PV RNase L ciRNA was found to function as a competitive inhibitor, it should inhibit the endoribonuclease domain of RNase L directly. Fragments of RNase L corresponding to the endoribonuclease domain exhibit endoribonuclease activity in the absence of 2-5A (Dong and Silverman 1997). We used a 6His-SUMOtagged $\Delta 577$ RNase L fragment to test whether PV ciRNA could inhibit 

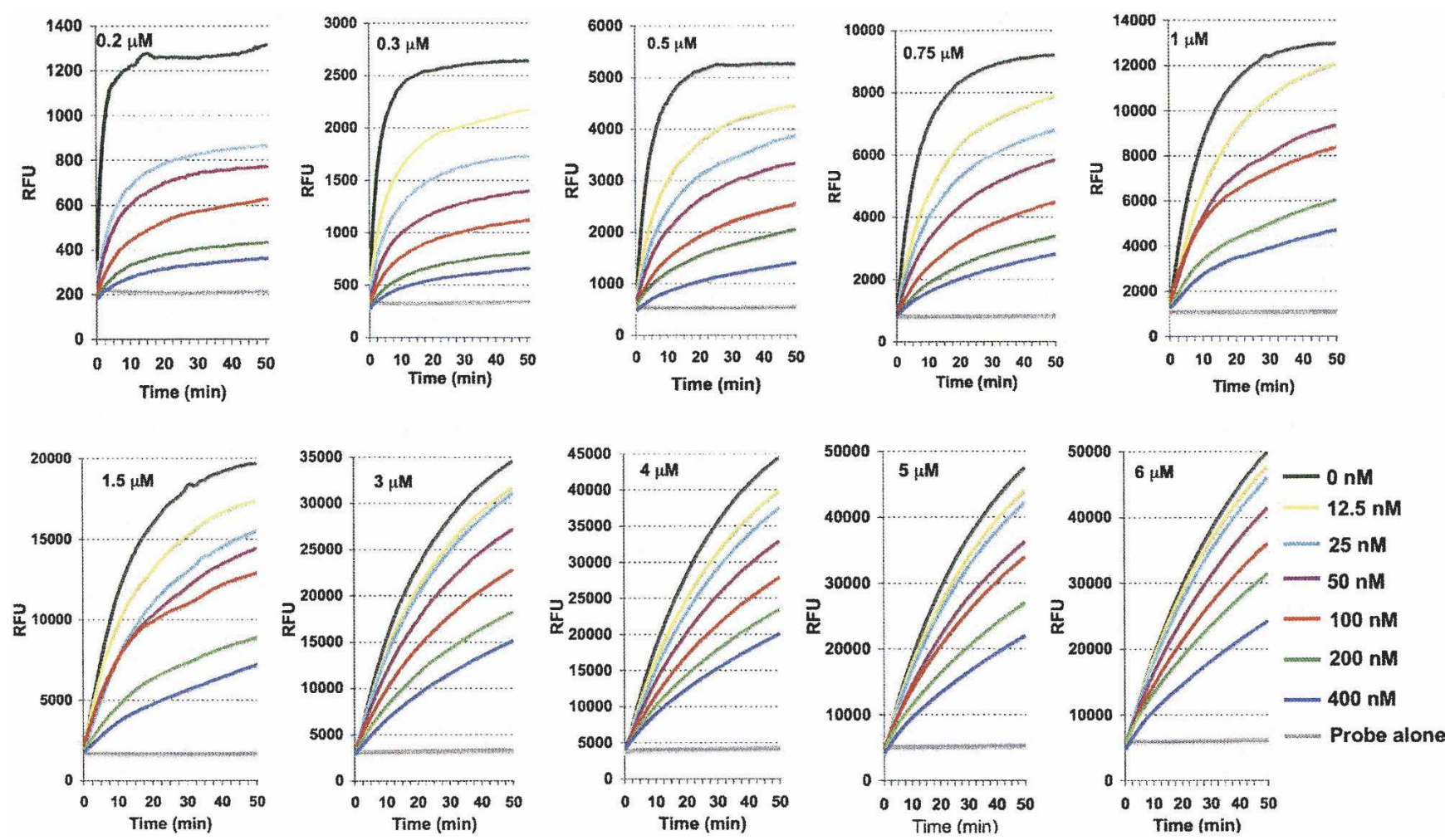

FIGURE 5. Kinetic analyses of ciRNA inhibition of RNase L. FRET reactions containing constant amounts of RNase L and 2-5A (20 nM each) along with $0.2 \mu \mathrm{M}, 0.3 \mu \mathrm{M}, 0.5 \mu \mathrm{M}, 0.75 \mu \mathrm{M}, 1 \mu \mathrm{M}, 1.5 \mu \mathrm{M}, 3 \mu \mathrm{M}, 4 \mu \mathrm{M}, 5 \mu \mathrm{M}$, and $6 \mu \mathrm{M}$ FRET probe and the indicated concentrations of PV ciRNA (0-400 nM). Fluorescence was detected every $15 \mathrm{sec}$ for $50 \mathrm{~min}$. Relative fluorescence units (RFU) plotted versus time of incubation.

the endoribonuclease domain directly (Fig. 7). In reactions with probe alone, RFUs remained unchanged over time (Fig. 7B,C); $300 \mathrm{nM}$ of 6 His-SUMOtagged $\Delta 577$ RNase L fragment cleaved the RNA probe over the two hour period of incubation (Fig. 7 B,C, $0 \mathrm{nM}$ ciRNA, black line). Increasing concentrations of $\mathrm{G}^{5761} \mathrm{~A}$ ciRNA had no substantial inhibitory effect beyond that of additional substrate whereas $\geq 75 \mathrm{nM}$ ciRNA dramatically inhibited the 300 $\mathrm{nM}$ of endoribonuclease domain fragment (Fig. 7C). Thus, the phylogenetically conserved RNA structure within the $3 \mathrm{C}^{\text {Protease }} \mathrm{ORF}$ of group C enteroviruses potently inhibited the activity of the RNase L endoribonuclease domain.

\section{DISCUSSION}

RNase $\mathrm{L}$ is well suited to biochemical characterization using either small defined RNA substrates with single cleavage sites (Carroll et al. 1997) or large viral RNAs with numerous cleavage sites (Han et al. 2004). Furthermore, defined RNA substrates like the FRET probe used in this investigation provide a relatively facile method to detect RNase L activity (Fig. 2; Thakur et al. 2005). In this study we sought to determine the mechanism by which a group C enterovirus RNA inhibited RNase L (Han et al. 2007). The data in this report indicate that an RNA structure within the ORF of group C enteroviruses functions as a competitive inhibitor of the endoribonuclease domain of RNase L (Figs. 5, 6). Based on the competitive inhibition profile one can conclude that the RNase L ciRNA binds to the same site as substrate RNAs (Fig. 1A), i.e., competing with substrate RNA binding. Consistent with the kinetic profile of a competitive inhibitor, the RNase L ciRNA did not affect $2-5 \mathrm{~A}$ binding to RNase L (Fig. 4) but did inhibit the constitutively active endoribonuclease domain of RNase L (Fig. 7). Synthetic RNA substrates containing $2^{\prime}$-deoxy-2'fluorouridine have been shown to inhibit RNase L (Ueno et al. 2003); however, the viral RNA described in this report is the first natural inhibitor of the endoribonuclease domain of RNase $\mathrm{L}$. The RNase L ciRNA inhibited cleavage of an RNA substrate with a $K_{i}$ of $34 \mathrm{nM}$ whereas the $K_{m}$ of substrate binding was $860 \mathrm{nM}$ (Table 1). The $K_{\text {cat }}$ for cleavage of the FRET probe was 5.9 per minute $(0.1$ per second, Table 1), lower than the $K_{\text {cat }}$ reported for a small unstructured RNA substrate with a single cleavage site $\left(\mathrm{C}_{11} \mathrm{U}_{2} \mathrm{C}_{7}, K_{\text {cat }}\right.$ of 4 per second as reported in Carroll et al. 1997). This difference in $K_{\text {cat }} s$ may be due to differences between the RNA substrates such as contextual features of UA and UU dinucleotides within the modestly more complex FRET probe used in our experiments (FRET probe illustrated in Fig. 2A) relative to the $\mathrm{C}_{11} \mathrm{U}_{2} \mathrm{C}_{7}$ RNA. For 


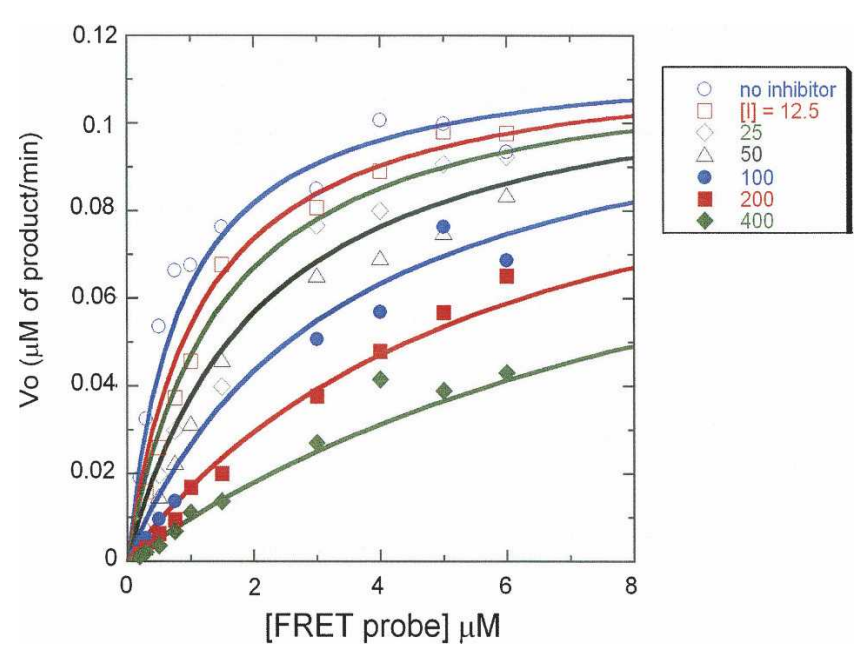

FIGURE 6. Competitive inhibition profiles of ciRNA on RNase L activity. The initial rates of FRET probe cleavage $\left(V_{0}\right)$ from the data in Figure 5 were determined and converted from RFU to $\mu \mathrm{M}$ of product per minute. Initial slopes were then plotted as a function of FRET probe concentration. Kaliedograph (Synergy Software) was used to generate the global fit analysis.

instance, the FRET probe used in our experiments assumes a secondary structure due to base-pairing (Thakur et al. 2007) whereas the $\mathrm{C}_{11} \mathrm{U}_{2} \mathrm{C}_{7}$ RNA is designed to avoid basepairing and is presumed to be unstructured. UA and UU dinucleotides within dsRNA are not cleaved by RNase L, and contextual features of UA and UU dinucleotides also appear to modulate the efficiency of cleavage by RNase L (Han et al. 2004). Furthermore, the FRET probe used in our experiments has several potential RNase L cleavage sites; however, RFUs will only increase following the initial cleavage event of the FRET probe and will not increase following additional cleavage events in the subsequent FRET probe fragments. Finally, other differences between the experiments in the different laboratories may contribute to the differences in reported $K_{\text {cat }}$ s, e.g., FRET assays of RNase L activity (herein) versus gel-based cleavage assays (Carroll et al. 1997).

The kinetic analyses indicate that RNase L ciRNA bound to the active site of RNase L 25-fold better than substrate ( $K_{i}$ of $34 \mathrm{nM}$ for the ciRNA versus $K_{m}$ of $860 \mathrm{nM}$ for FRET probe RNA substrate). A single point mutation at a key wobble position residue within the phylogenetically conserved ciRNA (Fig. 1, $\mathrm{G}^{5761} \mathrm{~A}$ ) abrogated the ability to inhibit RNase L (Fig. 3). It will be informative to determine the structural basis for this competitive inhibition of the endoribonuclease domain. Our current understanding of the ciRNA structure is that the region surrounding nucleotide G5761 is most critical for inhibition of RNase L while the stem-loop structures adjacent to this region appear to function as a benign structural backbone. The kissing interaction between stem-loops 1 and 4 is predicted by kinefold, and this pseudoknot contributes to the ability of the molecule to inhibit RNase L (Han et al. 2007). Thus, the RNase L ciRNA may assume a structure where stem-loops 1 and 4 lie adjacent to the region between them. This ciRNA fits into the substrate binding site of the endoribonuclease (Fig. 1A), preventing substrate binding and catalysis.

RNase L has three antiviral mechanisms that are not mutually exclusive. RNase $\mathrm{L}$ can cleave viral RNA ( $\mathrm{Li}$ et al. 1998; Han et al. 2004), promote apoptosis (Zhou et al. 1997; Domingo-Gil and Esteban 2006), and potentiate interferon- $\beta$ antiviral cytokine expression in an MDA5/ RIG-I/IPS-1-dependent manner (Malathi et al. 2007). RNase L can inhibit the replication of several viruses ( $\mathrm{Li}$ et al. 1998; Samuel et al. 2006; Scherbik et al. 2006) whereas other viruses may express effective countermeasures (Min and Krug 2006). It remains to be determined how the RNase L ciRNA contributes to group C enterovirus replication and pathogenesis (Han et al. 2007). If RNase L were to cleave viral RNA, one would expect to see reduced frequencies of UA and UU dinucleotides within the viral RNAs due to the selective pressure of RNase $\mathrm{L}$ cleavage at such sites (Washenberger et al. 2007). Group C enteroviruses do not have reduced frequencies of UA and UU dinucleotides characteristic of RNase L selective pressure (data not shown), suggesting that these viruses avoid cleavage of their RNAs by RNase L. The ciRNA described in this report may be important in this regard. Mutations in the ciRNA structure that abrogate inhibition of RNase L do not alter the kinetics or magnitude of PV replication; however, RNase $\mathrm{L}$ was activated late during the course of replication as virus assembly reached competition (Han et al. 2007). We speculate that activation of RNase $\mathrm{L}$ as virus assembly nears completion may trigger cytopathic effects on the host cell that potentiate the release of progeny virus that assemble and accumulate within the cytoplasm of infected cells. This possibility is supported by the formation of larger plaques in cells with RNase L activity relative to smaller plaques in cells without RNase L activity (Han et al. 2007). Thus, consistent with the possibility of ancient coevolutionary selection of antiviral innate immunity and viral countermeasures, group $\mathrm{C}$ enteroviruses may have evolved mechanisms to both evade and co-opt this antiviral pathway. The ability of a contemporary viral RNA to inhibit an antiviral endoribonuclease may offer a glimpse into the ancient RNA World (Maizels and Weiner 1999).

\begin{tabular}{|c|c|c|c|}
\hline $\begin{array}{l}K_{\text {cat }} \\
\left(\min ^{-1}\right)\end{array}$ & $\begin{array}{c}K_{m} \\
(\mathrm{nM})\end{array}$ & $\begin{array}{c}K_{\mathrm{cat}} / K_{m} \\
\left(\mathrm{M}^{-1} \mathrm{~s}^{-1}\right)\end{array}$ & $\begin{array}{c}K_{i} \\
(\mathrm{nM})\end{array}$ \\
\hline $5.9 \pm 0.3$ & $860 \pm 200$ & $1.17 \times 10^{5}$ & $34 \pm 8$ \\
\hline
\end{tabular}

Derived from data given in Figures 5 and 6. 
A RNase L

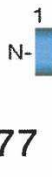

RNase L $\Delta 577$

B

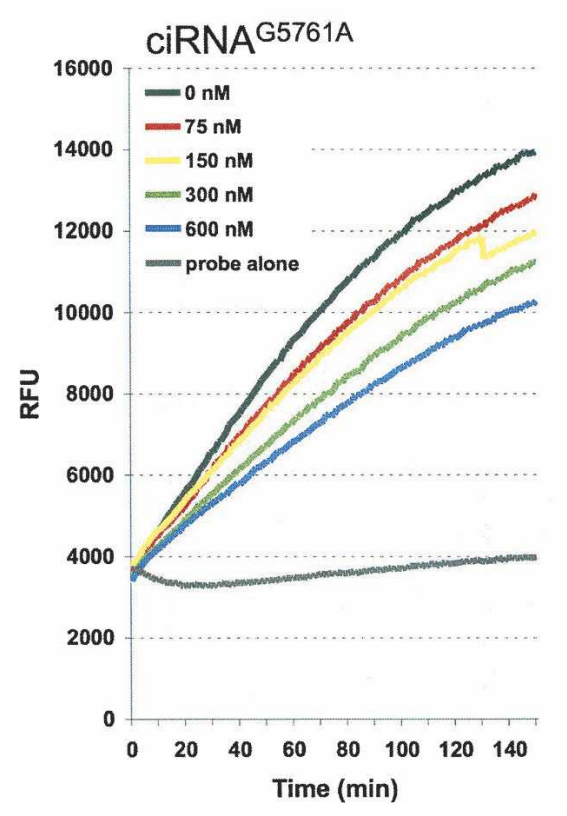

335364 $587 \quad 720741$ \begin{tabular}{|l|l|l|l|l|l|l|l|l|l|l}
1 & 2 & 3 & 4 & 5 & 6 & 7 & 8 & 9 & Kinase-Like & RNase \\
\hline
\end{tabular}

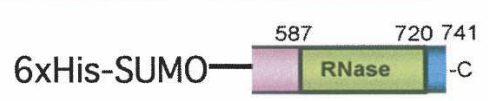

C

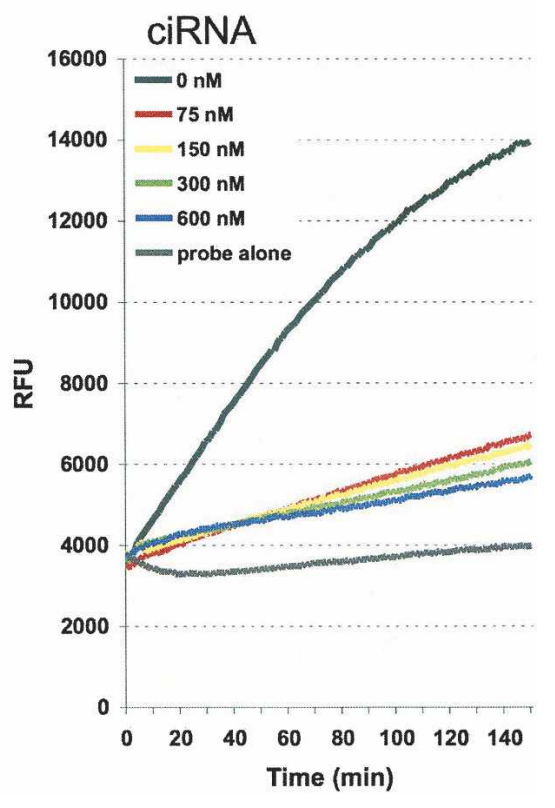

FIGURE 7. Viral RNA inhibition of the endoribonuclease domain of RNase L. (A) Diagrams of RNase L and the constitutively active $\Delta 577$ endoribonuclease domain of RNase L. $(B, C)$ FRET reactions containing $100 \mathrm{nM}$ of FRET probe and $300 \mathrm{nM} \Delta 577$ RNase L endoribonuclease domain (black line) as described in Materials and Methods. FRET reaction containing $100 \mathrm{nM}$ of probe without RNase L or 2-5A (gray line). FRET reactions containing $100 \mathrm{nM}$ of FRET probe, $300 \mathrm{nM} \Delta 577$ RNase L, and the indicated concentrations of ciRNA ${ }^{\mathrm{G} 5761 \mathrm{~A}}(B)$ or wild-type ciRNA $(C)$. Relative fluorescence units (RFU) plotted versus time of incubation.

\section{MATERIALS AND METHODS}

\section{RNase L}

RNase L was expressed and purified as previously described (Zhou et al. 1993; Silverman et al. 2000; Rusch et al. 2001), with modifications. Briefly, untagged recombinant human RNase $\mathrm{L}$ in a baculovirus vector was expressed in SF21 insect cells. Suspension cultures of SF21 cells were grown in SFM 900 insect cell medium (Invitrogen) supplemented with $10 \%$ fetal bovine serum to a cell density of $1.5 \times 10^{6}$ to $2.0 \times 10^{6}$ cells $/ \mathrm{mL}$. Cells were infected at a multiplicity of infection (MOI) of $5 \mathrm{PFU}$ per cell at $27^{\circ} \mathrm{C}$ for $72 \mathrm{~h}$ before being harvested. The cell pellets were washed with chilled phosphate-buffered saline (PBS), resuspended in lysis buffer (20 mM HEPES, $\mathrm{pH} 7.4,5 \mathrm{mM} \mathrm{MgCl}_{2}, 50 \mathrm{mM} \mathrm{KCl}, 1 \mathrm{mM}$ EDTA, $10 \%$ glycerol, $14 \mathrm{mM}$ 2-mercaptoethanol [2-ME], $100 \mu \mathrm{M}$ ATP, $20 \mu \mathrm{g} / \mathrm{mL}$ leupeptin, $20 \mu \mathrm{g} / \mathrm{mL}$ pepstatin, $50 \mu \mathrm{M}$ phenylmethylsulfonyl fluoride [PMSF]), and disrupted with a French press. Supernatants were collected after centrifugation at $100,000 \mathrm{~g}$ and incubated for $1 \mathrm{~h}$ at $4^{\circ} \mathrm{C}$ with CL6B Blue Sepharose affinity resin (Amersham Bioscience). The protein-bound affinity resin was packed in an HR16/24 column and washed with buffer A (20 mM HEPES, pH 7.4, 5 $\mathrm{mM} \mathrm{MgCl}_{2}, 50 \mathrm{mM} \mathrm{KCl}, 1 \mathrm{mM}$ EDTA, 10\% glycerol, 7 mM 2-ME, $100 \mu \mathrm{M}$ ATP, $2 \mu \mathrm{g} /$ $\mathrm{mL}$ leupeptin, $2 \mu \mathrm{g} / \mathrm{mL}$ pepstatin, $50 \mu \mathrm{M}$ PMSF). The bound RNase L was eluted with a $0 \%-100 \%$ linear gradient of buffer B (20 mM HEPES, pH 7.4, $5 \mathrm{mM} \mathrm{MgCl}_{2}, 1.0 \mathrm{M}$ $\mathrm{KCl}, 1 \mathrm{mM}$ EDTA, 10\% glycerol, $7 \mathrm{mM} 2-$ ME, $100 \mu \mathrm{M}$ ATP, $2 \mu \mathrm{g} / \mathrm{mL}$ leupeptin, $2 \mu \mathrm{g} /$ $\mathrm{mL}$ pepstatin, $50 \mu \mathrm{M}$ PMSF) over a period of $1 \mathrm{~h}$ at a flow rate of $1 \mathrm{~mL} / \mathrm{min}$. The peak fractions containing RNase L were pooled, dialyzed against four changes of buffer A, loaded onto a MonoQ HR 10/10 column, and eluted with a $0 \%-50 \%$ buffer B gradient over a period of $60 \mathrm{~min}$ at a flow rate of $1 \mathrm{~mL} / \mathrm{min}$. The purity of RNase $\mathrm{L}$ was $>90 \%$, as judged by sodium dodecyl sulfate (SDS)-polyacrylamide gel electrophoresis followed by Coomassie blue staining.

\section{Nuclease domain of RNase L N $\mathbf{\Delta 5 7 7}$}

A 495-bp cDNA encoding 578-741 residues of the C-terminal nuclease domain of human RNase L was PCR-amplified from pcDNA3.1-Neo.ZC5 (Zhou et al. 1993) with forward primer 5 '-AGTGACCTGCTGGGT CATC-3' and reverse primer $5^{\prime}$-TCAGTC TTCAGCAGgagGgTGAAA- ${ }^{\prime}$. The PCRamplified insert was cloned in pET-SUMO (Invitrogen) using Champion ${ }^{\mathrm{TM}}$ pETSUMO TA Cloning kit (Invitrogen) according to manufacturer's instructions and named pETSUMO-RLNuc. The integrity of the sequence was verified by sequencing. Escherichia coli BL21-DE3 chemically competent cells (Invitrogen) were transformed with the plasmid pETSUMO$\mathrm{N} \Delta 577$. A single colony was isolated and allowed to grow overnight in LB medium containing $2 \%$ glucose. One percent $(40 \mathrm{~mL})$ of overnight culture was inoculated in 4-L LB medium containing $0.2 \%$ of glucose at $37^{\circ} \mathrm{C}$ until the $\mathrm{OD}^{600 \mathrm{~nm}}$ of the culture reached 0.6. The culture was cooled to $25^{\circ} \mathrm{C}$ and expression was induced with $0.3 \mathrm{mM}$ isopropyl-1-thio- $\beta$-D-galactopyranoside. The bacterial cells were collected after an additional $6 \mathrm{~h}$ of incubation at $25^{\circ} \mathrm{C}$ by centrifugation at $5000 \mathrm{~g}$ for $10 \mathrm{~min}$. The cell pellet was resuspended in buffer A (25 mM Tris- $\mathrm{HCl}$ [pH 7.5], $300 \mathrm{mM} \mathrm{KCl}$, $50 \mu \mathrm{M}$ EDTA, 7 mM $\beta$-mercaptoethanol, 10\% glycerol) containing complete EDTA-free protease inhibitor cocktail (Roche Applied Sciences), and then subjected to disruption by sonication on ice. Cell debris was removed from the homogenate by centrifugation at $15,000 \mathrm{~g}$ for $30 \mathrm{~min}$ at $4^{\circ} \mathrm{C}$. The supernatant was loaded onto a Talon-metal affinity resin (BD Biosciences Clontech) charged with $\mathrm{Ni}^{++}$and pre-equilibrated with buffer A. After an extensive wash with buffer A to obtain a stable base line, RNase L N $\Delta 577$ was eluted from the column with buffer A containing a linear gradient of imidazole, from 0 to $200 \mathrm{mM}$ at a flow rate of $0.5 \mathrm{~mL} / \mathrm{min}$ over a period of $1 \mathrm{~h}$. Peak fractions were 
subjected to SDS-PAGE analysis and the fractions containing the protein of interest were pooled. The pooled fractions were combined and passed over desalting column pre-equilibrated with buffer B (25 mM Tris- $\mathrm{HCl}$ [pH 7.5], $50 \mathrm{mM} \mathrm{KCl,} 7 \mathrm{mM} \beta$ mercaptoethanol, $10 \%$ glycerol). The pooled fractions after desalting were subsequently loaded onto a Uno-S (Biorad) resin (bed volume: $10 \mathrm{~mL}$ ) pre-equilibrated with buffer B. Elution was carried out with buffer $\mathrm{B}$ containing a linear gradient of $\mathrm{NaCl}$, from 0 to $1 \mathrm{M}$ over a time of $1 \mathrm{~h}$ at a flow rate of $1 \mathrm{~mL} / \mathrm{min}$. The peak fraction was pooled and analyzed by SDS-PAGE analysis followed by Western blot analysis using anti-hexa-His antibodies, His-Probe (Santa Cruz Biotechnology). The activity of the protein was tested by FRET assay (Thakur et al. 2005).

\section{2-5A}

Enzymatic Synthesis of 2-5A from ATP was done with recombinant porcine $2 '-5$ ' oligoadenylate synthetase (pOAS1) (a generous gift of Rune Hartmann, Aarhus, Denmark) activated with poly(I): poly $(\mathrm{C})$ conjugated to CL6B agarose (Ag-pI:pC). Briefly, poly(I): poly $(\mathrm{C})$ was conjugated with CL6B agarose beads (Amersham Biosciences) using per-iodate conjugation chemistry, and Agpoly(I):poly(C) was incubated with $0.4 \mathrm{mg} / \mathrm{mL}$ of purified pOAS1 at $25^{\circ} \mathrm{C}$ in $10 \mathrm{mM}$ HEPES pH 7.5 containing $1.5 \mathrm{mM}$ magnesium acetate, $20 \%$ glycerol, $50 \mathrm{mM} \mathrm{KCl}$, and $7 \mathrm{mM} \beta$-mercaptoethanol for $1 \mathrm{~h}$. pOAS1 immobilized on Ag-pI:pC beads was washed three times with buffer (10 mM HEPES pH 7.5 containing $1.5 \mathrm{mM}$ magnesium acetate, $20 \%$ glycerol, $50 \mathrm{mM} \mathrm{KCl}$, and $7 \mathrm{mM} \beta$ mercaptoethanol) and resuspended in the reaction mixture (10 $\mathrm{mM}$ ATP in $1.5 \mathrm{mM}$ magnesium acetate, $20 \%$ glycerol, $50 \mathrm{mM}$ $\mathrm{KCl}$, and $7 \mathrm{mM} \beta$-mercaptoethanol) for $20 \mathrm{~h}$. The unfractionated 2-5A mixture was harvested by centrifugation at $3000 \mathrm{~g}$ for 15 min. The unfractionated 2-5A mix was separated from pOAS1 using Centriprep (Millipore) molecular weight cutoff of $3000 \mathrm{Da}$. The 2-5A was analyzed by injecting $50 \mu \mathrm{L}$ of $1: 10$ diluted stock of 2-5A mix on Dionex P100 $4 \times 250$ analytical column (Dionex Inc.) interfaced with System gold HPLC connected to a 32 Karat work station in $25 \mathrm{mM}$ Tris- $\mathrm{HCl} \mathrm{pH} 7.5$ and eluted with a gradient of $0-750 \mathrm{mM} \mathrm{NaCl}$ in $25 \mathrm{mM}$ Tris- $\mathrm{HCl}$ in $1 \mathrm{~h}$. The large scale purification was done on MonoQ column HR10/10 (Amersham Biosciences) interfaced with FPLC (Amersham Biosciences) and characterized by HPLC.

\section{Viral RNA}

cDNA encoding the poliovirus RNA inhibitor of RNase L (illustrated in Fig. 1B) was amplified by PCR using a $5^{\prime}$ primer with a T7 transcription promoter (underlined) (5'-GAAATTAA TACGACTCACTATAGGATCGTGAACACTAGCAAGTACCCCA ATATG-3') and a $3^{\prime}$ reverse primer (5'-GGATCGCTTCAGG GCCGCTGCAAACCCGTGTGAACC-3'). A $\mathrm{G}^{5761} \mathrm{~A}$ mutation was engineered into the cDNA by PCR using the primer $5^{\prime}$ GAAATTAATACGACTCACTATAGGATCGTGAACACTAGCAA $\mathrm{A}^{5761}$ TACCCCAATATG-3'. PCR-generated cDNAs were transcribed by T7 polymerase (Epicentre). Viral RNAs were precipitated with $0.3 \mathrm{M}$ sodium acetate $(\mathrm{pH} 7.0)$ and two volumes of ethanol, washed with 70\% ethanol, and solubilized in water. RNAs were qualitatively and quantitatively analyzed by electrophoresis in $1 \%$ agarose, ethidium bromide staining and visualization with UV light.

\section{FRET assay of RNase L activity}

A dual-labeled RNA FRET probe was used as a substrate to monitor RNase L activity (Thakur et al. 2005). The substrate was derived from a 36-nt intergenic sequence of respiratory syncytial virus (RSV) (UUAUCAAAUUCUUAUUUGCCCCAUUUUUU UGGUUUA) with a fluorophore (6FAM or 6-carboxyfluorescein) at the $5^{\prime}$ terminus and a BHQ1 at the $3^{\prime}$ terminus (Sigma-Proligo) (Fig. 2A). Reactions $(50 \mu \mathrm{L})$ contained $25 \mathrm{mM}$ Tris- $\mathrm{HCl}$ ( $\mathrm{pH} 7.4$ ), $100 \mathrm{mM} \mathrm{KCl}, 10 \mathrm{mM} \mathrm{MgCl}_{2}, 50 \mu \mathrm{M}$ ATP, $7 \mathrm{mM} \beta$-mercaptoethanol, $100 \mathrm{nM}$ FRET probe, variable amounts of viral RNA (0$600 \mathrm{nM}$ ), and either full-length RNase L and 2-5A (20 nM each) or $\Delta 577$ RNase L $(300 \mathrm{nM})$ as indicated in figure legends. Reactions were incubated at room temperature in a black 96 -well microtiter round bottom plate. Fluorescence was activated using $485 \mathrm{~nm}$ wavelength excitation; 535-nm wavelength emissions were detected at the indicated times in a Bio-Tek Synergy HT MultiDetection Microplate Reader.

\section{2-5A binding assay}

96-well assay plates were coated with $100 \mu \mathrm{L}$ of RNase L $(10 \mu \mathrm{g} /$ $\mathrm{mL}$ ), i.e., $1 \mu \mathrm{g} /$ well, and incubated with increasing amounts of PV RNA 2122, $\Delta 1, \Delta 2, \Delta 3$ RNA derivatives and unlabeled 2-5A (0$400 \mathrm{nM}$ ) for $10 \mathrm{~min}$ at room temperature. A final concentration of $10 \mathrm{nM}$ of biotin labeled $2-5 \mathrm{~A}$ was added to each well containing either unlabeled RNA or 2-5A. The plates were incubated for $1 \mathrm{~h}$ at room temperature. The solution was removed and wells were washed five times with $10 \mathrm{mM}$ phosphate buffered saline containing $0.05 \%$ of Tween-20. After washing, the bound $2-5 \mathrm{~A}$ was probed with supersensitive Streptavidin-HRP (Sigma) and developed with TMB (Sigma). The reaction was stopped after 5$7 \mathrm{~min}$ by adding $100 \mu \mathrm{L}$ of $2 \mathrm{~N}-\mathrm{HCl}$ and OD was read at $405 \mathrm{~nm}$. Each data point is the average of three and representative of two experiments.

\section{Steady state kinetic analyses}

FRET reactions containing $20 \mathrm{nM}$ RNase L, $20 \mathrm{nM}$ 2-5A, 0-400 nM RNase L ciRNA, and 0.2-6 $\mu \mathrm{m}$ FRET probe were incubated at room temperature in a black 96 -well microtiter round bottom plate. Fluorescence was activated using $485-\mathrm{nm}$ wavelength excitation; 535-nm wavelength emissions were detected at the same sensitivity $(S=55)$ at the indicated times in a Bio-Tek Synergy HT Multi-Detection Microplate Reader. Initial velocity $\left(V_{0}\right)$ was determined for each substrate concentration at each PV RNA concentration by plotting the first two minutes of each curve and calculating the slope of the line. $\mathrm{V}_{\mathrm{o}}$ was then plotted as a function of substrate concentration using a global fit analysis equation (Equation 1) generated by Scientist Software (Micromath).

$$
V_{0}=\frac{V_{\max } S_{0}}{K_{m}\left(1+[I] / K_{i}\right)+S_{0}} .
$$

\section{ACKNOWLEDGMENTS}

We thank Chris Washenberger for information regarding group C enterovirus sequence alignments and Rune Hartmann (Aarhus, 
Denmark) for the pOAS1 clone. This work was supported by the American Cancer Society Research Scholar Grant RSG-02-063-01MBC and by Public Health Service grants AI42189, CA44059, and T32 AI052066.

Received December 17, 2007; accepted February 18, 2008.

\section{REFERENCES}

Ahlquist, P. 2006. Parallels among positive-strand RNA viruses, reverse-transcribing viruses, and double-stranded RNA viruses. Nat. Rev. Microbiol. 4: 371-382.

Benoit De Coignac, A., Bisbal, C., Lebleu, B., and Salehzada, T. 1998. cDNA cloning and expression analysis of the murine ribonuclease L inhibitor. Gene 209: 149-156.

Bisbal, C., Martinand, C., Silhol, M., Lebleu, B., and Salehzada, T. 1995. Cloning and characterization of a RNAse L inhibitor. A new component of the interferon-regulated 2-5A pathway. J. Biol. Chem. 270: 13308-13317.

Bisbal, C., Salehzada, T., Silhol, M., Martinand, C., Le Roy, F., and Lebleu, B. 2001. The 2-5A/RNase L pathway and inhibition by RNase L inhibitor (RLI). Methods Mol. Biol. 160: 183-198.

Carroll, S.S., Cole, J.L., Viscount, T., Geib, J., Gehman, J., and Kuo, L.C. 1997. Activation of RNase L by $2^{\prime}, 5^{\prime}$-oligoadenylates. Kinetic characterization. J. Biol. Chem. 272: 19193-19198.

Desai, S.Y. and Sen, G.C. 1997. Effects of varying lengths of doublestranded RNA on binding and activation of $2^{\prime}-5^{\prime}$-oligoadenylate synthetase. J. Interferon Cytokine Res. 17: 531-536.

Domingo-Gil, E. and Esteban, M. 2006. Role of mitochondria in apoptosis induced by the $2-5 \mathrm{~A}$ system and mechanisms involved. Apoptosis 11: 725-738.

Dong, B. and Silverman, R.H. 1995. 2-5A-dependent RNase molecules dimerize during activation by $2-5$ A. J. Biol. Chem. 270: 4133-4137.

Dong, B. and Silverman, R.H. 1997. A bipartite model of 2-5Adependent RNase L. J. Biol. Chem. 272: 22236-22242.

Dong, B. and Silverman, R.H. 1999. Alternative function of a protein kinase homology domain in $2^{\prime}, 5^{\prime}$-oligoadenylate dependent RNase L. Nucleic Acids Res. 27: 439-445. doi: 10.1093/nar/ 27.2.439.

Dong, B., Niwa, M., Walter, P., and Silverman, R.H. 2001. Basis for regulated RNA cleavage by functional analysis of RNase $\mathrm{L}$ and Ire1p. RNA 7: 361-373.

Floyd-Smith, G., Slattery, E., and Lengyel, P. 1981. Interferon action: RNA cleavage pattern of a $\left(2^{\prime}-5^{\prime}\right)$ oligoadenylate-dependent endonuclease. Science 212: 1030-1032.

Gale Jr., M. and Foy, E.M. 2005. Evasion of intracellular host defence by hepatitis C virus. Nature 436: 939-945.

Garcia-Sastre, A. 2004. Identification and characterization of viral antagonists of type I interferon in negative-strand RNA viruses. Curr. Top. Microbiol. Immunol. 283: 249-280.

Geselowitz, D.A., Cramer, H., Wondrak, E.M., Player, M.R., and Torrence, P.F. 2000. Fluorescence resonance energy transfer analysis of RNase L-catalyzed oligonucleotide cleavage. Antisense Nucleic Acid Drug Dev. 10: 45-51.

Goodbourn, S., Didcock, L., and Randall, R.E. 2000. Interferons: Cell signaling, immune modulation, antiviral response, and virus countermeasures. J. Gen. Virol. 81: 2341-2364.

Haller, O., Kochs, G., and Weber, F. 2006. The interferon response circuit: Induction and suppression by pathogenic viruses. Virology 344: 119-130.

Han, J.Q., Wroblewski, G., Xu, Z., Silverman, R.H., and Barton, D.J. 2004. Sensitivity of hepatitis C virus RNA to the antiviral enzyme ribonuclease $\mathrm{L}$ is determined by a subset of efficient cleavage sites. J. Interferon Cytokine Res. 24: 664-676.

Han, J.Q., Townsend, H.L., Jha, B.K., Paranjape, J.M., Silverman, R.H., and Barton, D.J. 2007. A phylogenetically conserved RNA structure in the poliovirus open reading frame inhibits the antiviral endoribonuclease RNase L. J. Virol. 81: 55615572.

Hartmann, R., Justesen, J., Sarkar, S.N., Sen, G.C., and Yee, V.C. 2003. Crystal structure of the 2 '-specific and double-stranded RNAactivated interferon-induced antiviral protein $2^{\prime}-5^{\prime}$-oligoadenylate synthetase. Mol. Cell 12: 1173-1185.

Lee, K.P., Dey, M., Neculai, D., Cao, C., Dever, T.E., and Sicheri, F. 2008. Structure of the dual enzyme Irel reveals the basis for catalysis and regulation in nonconventional RNA splicing. Cell 132: $89-100$.

Li, X.L., Blackford, J.A., and Hassel, B.A. 1998. RNase L mediates the antiviral effect of interferon through a selective reduction in viral RNA during encephalomyocarditis virus infection. J. Virol. 72: 2752-2759.

Maizels, N. and Weiner, A.M. 1999. The genomic tag hypothesis: What molecular fossils tell us about the evolution of tRNA. In The RNA world, 2d ed. (eds. R.F. Gesteland et al.), pp. 79-111. Cold Spring Harbor Laboratory Press, Cold Spring Harbor, NY.

Malathi, K., Dong, B., Gale Jr., M., and Silverman, R.H. 2007. Small self-RNA generated by RNase L amplifies antiviral innate immunity. Nature 448: 816-819.

Mathews, D.H., Sabina, J., Zuker, M., and Turner, D.H. 1999. Expanded sequence dependence of thermodynamic parameters improves prediction of RNA secondary structure. J. Mol. Biol. 288: 911-940.

Min, J.Y. and Krug, R.M. 2006. The primary function of RNA binding by the influenza A virus NS1 protein in infected cells: Inhibiting the $2^{\prime}-5$ ' oligo (A) synthetase/RNase L pathway. Proc. Natl. Acad. Sci. 103: 7100-7105.

Nakanishi, M., Tanaka, N., Mizutani, Y., Mochizuki, M., Ueno, Y., Nakamura, K.T., and Kitade, Y. 2005. Functional characterization of 2',5'-linked oligoadenylate binding determinant of human RNase L. J. Biol. Chem. 280: 41694-41699.

Player, M.R. and Torrence, P.F. 1998. The 2-5A system: Modulation of viral and cellular processes through acceleration of RNA degradation. Pharmacol. Ther. 78: 55-113.

Rusch, L., Dong, B., and Silverman, R.H. 2001. Monitoring activation of ribonuclease L by $2^{\prime}, 5^{\prime}$-oligoadenylates using purified recombinant enzyme and intact malignant glioma cells. Methods Enzymol. 342: $10-20$.

Samuel, M.A., Whitby, K., Keller, B.C., Marri, A., Barchet, W., Williams, B.R., Silverman, R.H., Gale Jr., M., and Diamond, M.S. 2006. PKR and RNase L contribute to protection against lethal West Nile Virus infection by controlling early viral spread in the periphery and replication in neurons. J. Virol. 80: 7009-7019.

Scherbik, S.V., Paranjape, J.M., Stockman, B.M., Silverman, R.H., and Brinton, M.A. 2006. RNase L plays a role in the antiviral response to West Nile Virus. J. Virol. 80: 2987-2999.

Segel, I.H. 1975. Enzyme kinetics: Behavior and analysis of rapid equilibrium and steady state enzyme systems. Wiley, New York.

Silverman, R.H. 2007. Viral encounters with OAS and RNase L during the IFN antiviral response. J. Virol. doi: 10.1128/JVI.01471-07.

Silverman, R.H., Dong, B., Maitra, R.K., Player, M.R., and Torrence, P.F. 2000. Selective RNA cleavage by isolated RNase L activated with 2-5A antisense chimeric oligonucleotides. Methods Enzymol. 313: 522-533.

Straume, M. and Johnson, M.L. 1992. Monte Carlo method for determining complete confidence probability distributions of estimated model parameters. Methods Enzymol. 210: 117-129.

Tanaka, N., Nakanishi, M., Kusakabe, Y., Goto, Y., Kitade, Y., and Nakamura, K.T. 2004. Structural basis for recognition of $2^{\prime}, 5^{\prime}-$ linked oligoadenylates by human ribonuclease L. EMBO J. 23: 3929-3938.

Thakur, C.S., Xu, Z., Wang, Z., Novince, Z., and Silverman, R.H. 2005. A convenient and sensitive fluorescence resonance energy transfer assay for RNase L and 2',5' oligoadenylates. Methods Mol. Med. 116: 103-113. 
Thakur, C.S., Jha, B.K., Dong, B., Das Gupta, J., Silverman, K.M., Mao, H., Sawai, H., Nakamura, A.O., Banerjee, A.K., Gudkov, A., et al. 2007. Small-molecule activators of RNase L with broadspectrum antiviral activity. Proc. Natl. Acad. Sci. 104: 95859590.

Ueno, Y., Yamada, Y., Nakanishi, M., and Kitade, Y. 2003. A specific substrate-inhibitor, a 2'-deoxy-2'-fluorouridine-containing oligoribonucleotide, against human RNase L. Bioorg. Med. Chem. 11: 5069-5073.

Wang, Q. and Carmichael, G.G. 2004. Effects of length and location on the cellular response to double-stranded RNA. Microbiol. Mol. Biol. Rev. 68: 432-452.

Washenberger, C.L., Han, J.Q., Kechris, K.J., Jha, B.K., Silverman, R.H., and Barton, D.J. 2007. Hepatitis C virus RNA: Dinucleotide frequencies and cleavage by RNase L. Virus Res. 130: 85-95.
Wreschner, D.H., McCauley, J.W., Skehel, J.J., and Kerr, I.M. 1981. Interferon action-Sequence specificity of the $\operatorname{ppp}\left(\mathrm{A} 2^{\prime} \mathrm{p}\right) \mathrm{nA}-$ dependent ribonuclease. Nature 289: 414-417.

Xayaphoummine, A., Bucher, T., and Isambert, H. 2005. Kinefold web server for RNA/DNA folding path and structure prediction including pseudoknots and knots. Nucleic Acids Res. 33: W605-W610.

Zhou, A., Hassel, B.A., and Silverman, R.H. 1993. Expression cloning of 2-5A-dependent RNAase: A uniquely regulated mediator of interferon action. Cell 72: 753-765.

Zhou, A., Paranjape, J., Brown, T.L., Nie, H., Naik, S., Dong, B., Chang, A., Trapp, B., Fairchild, R., Colmenares, C., et al. 1997. Interferon action and apoptosis are defective in mice devoid of 2',5'-oligoadenylate-dependent RNase L. EMBO J. 16: 6355-6363.

Zuker, M. 2003. Mfold web server for nucleic acid folding and hybridization prediction. Nucleic Acids Res. 31: 3406-3415. doi: 10.1093/nar/gkg595. 

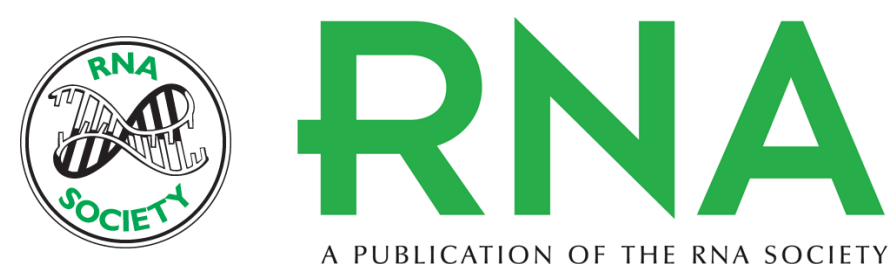

A PUBLICATION OF THE RNA SOCIETY

\section{A viral RNA competitively inhibits the antiviral endoribonuclease domain of RNase L}

Hannah L. Townsend, Babal K. Jha, Jian-Qiu Han, et al.

RNA 2008 14: 1026-1036

References This article cites 44 articles, 16 of which can be accessed free at: http://rnajournal.cshlp.org/content/14/6/1026.full.html\#ref-list-1

\section{License}

Email Alerting Receive free email alerts when new articles cite this article - sign up in the box at the Service top right corner of the article or click here. 